\title{
Translation as Commentary in the Sanskrit-Old Javanese Didactic and Religious Literature from Java and Bali
}

\author{
Andrea Acri and Thomas M. Hunter*
}

This article discusses the dynamics of translation and exegesis documented in the body of Sanskrit-Old Javanese Śaiva and Buddhist technical literature of the tutur/tattva genre, composed in Java and Bali in the period from c. the ninth to the sixteenth century. The texts belonging to this genre, mainly preserved on palm-leaf manuscripts from Bali, are concerned with the reconfiguration of Indic metaphysics, philosophy, and soteriology along localized lines. Here we focus on the texts that are built in the form of Sanskrit verses provided with Old Javanese prose exegesis - each unit forming a "translation dyad«. The Old Javanese prose parts document cases of linguistic and cultural »localization« that could be regarded as broadly corresponding to the Western categories of translation, paraphrase, and commentary, but which often do not fit neatly into any one category.

Having introduced the "vyākhya-style« form of commentary through examples drawn from the early inscriptional and didactic literature in Old Javanese, we present key instances of "cultural translations" as attested in texts composed at different times and in different geographical and religio-cultural milieus, and describe their formal features. Our aim is to document how local agents (re-)interpreted, fractured, and restated the messages conveyed by the Sanskrit verses in the light of their contingent contexts, agendas, and prevalent exegetical practices. Our hypothesis is that local milieus of textual production underwent a progressive "drift « from the Indic-derived scholastic traditions that inspired - and entered into a conversation with - the earliest sources, composed in Central Java in the early medieval period, and progressively shifted towards a more embedded mode of production in East Java and Bali from the eleventh to the sixteenth century and beyond.

Keywords: Old Javanese; Sanskrit; tutur; tattva; commentarial literature; Śaivism; Buddhism

* Correspondence details: Andrea Acri, Section des Sciences religieuses, École Pratique des Hautes Études (EPHE, PSL University), Les Patios Saint-Jacques, 4-14 rue Ferrus, 75014 Paris, France; email: andrea.acri@ephe.psl.eu. Thomas M. Hunter, Department of Asian Studies, The University of British Columbia, 607-1871 West Mall, Vancouver, BC, Canada V6T oC2; email: thomas.hunter@ubc.ca. 


\section{Introduction}

A significant body of literature in Old Javanese, composed mainly in the period from c. the ninth to the fifteenth century, has come down to us from Java, Bali, and the nearby island of Lombok through palm-leaf manuscripts. This body of literature may be regarded as a relic of the region's Indic past, testifying to the process of appropriation and hybridization by local milieus of linguistic, cultural, and religious material derived from the Sanskritic world that mainly unfolded during the "post-Gupta" South Asian medieval period - a process that largely coincides with the global Middle Ages, of which Indonesia was an integral part. ${ }^{1}$ During that period, the pedagogical institutions of urban centres and religious complexes of the Malay-Indonesian archipelago were part of the translocal culture first described by Pollock ${ }^{2}$ under the terms "Sanskrit cosmopolis" and "Sanskrit ecumene«. Indic forms of writing and textual organization had arrived in the archipelago along with the Buddhist monks, Śaiva masters, and other religious wanderers who depended on textual means to preserve the continuity of religious doctrine.

In what follows we review the history of didactic and prose composition in the Old Javanese language as reflecting a tradition of translation that adheres to the norms of standard Indian Sanskritic models of the commentary, but uses Old Javanese rather than Sanskrit as the language of exegesis. The resulting form of text-building in Old Javanese has had a long life in the archipelago, extending from its original domain in theological and didactic works into prose works like the parva literature translating several books of the Mahäbhärata and later prose works like the Tantri Kämandaka - a collection of animal tales embedded in a Scheherazade-like framing tale - as well as the numerically significant genre of Śaiva (and, to a much lesser extent, Buddhist) technical texts called tutur or tattva concerned with the reconfiguration of Sanskrit-derived metaphysics, philosophy, and soteriology along localized lines. ${ }^{3}$ In this article we will focus on this body of Sanskrit-Old Javanese didactic literature, many important specimens of which are arranged in the form of a Sanskrit verse or a series of verses (whether quoted in their entirety or separated into their discrete units/pāda) provided with an Old Javanese prose translation and/or exegesis - each unit forming a socalled »translation dyad«.

One of the unifying factors of the Middle Ages across Maritime Asia was the multi-centric spread and circulation of (Sanskritic) Buddhism as well as Śaivism; on the former, see Acri, Esoteric Buddhism.

2 Pollock, Sanskrit cosmopolis.

3 In fact, this tradition would appear to have continued beyond the premodern "Hindu-Buddhist « period, for contemporary evidence for the continuing effects of a "śästra model« of composition may be found in the "Yellow Books « explicating passages of the Qur'an or Hadith into Indonesian or Javanese and in the practice of the sekaha mabasan clubs of modern Bali. These clubs are characterized by »extemporaneous glossing " using hermeneutical strategies that do not (primarily) involve analytical means, drawn from a systematic knowledge of morphology and grammar, or try to establish historical derivations and etymologies; they are mainly based on contemporary/ popular lexical know-how, »folk etymology«, and associative thinking effected through homology, metaphor, and assonance. These techniques are akin to the Sanskrit nirvacana, which unpack meanings from words rather than reduce them to their bare essentials. 
Earlier work by Hunter ${ }^{4}$ traced some of the defining features of this literature in a study of the question of "translation« into Old Malay and Old Javanese. He suggested that for premodern insular Southeast Asia processes of translation are best understood in terms of a "culture of diglossia" that has its roots in the parallelism of Sanskrit and Prakrit in the inscriptions and dramatic forms of South Asia, and that features of textual diglossia - which are most prominent in the Old Javanese didactic tradition - must certainly be linked to pedagogical institutions. In these institutions the transmission of theological and philosophical ideas, and the formulation of literary practices, depended on an ongoing practice of translation that we find embodied in a number of characteristic modes of textual organization. The Old Javanese prose parts reflect dynamics of linguistic and cultural »localization « that could be regarded as broadly corresponding to the Western categories of translation, paraphrase, and commentary, but which often do not fit neatly into any one category, for they include multiple intents and agendas at once. Indeed, we could regard the kind of intellectual operation carried out by ancient Javanese and Balinese authors as a »translation as commentary" involving multiple processes simultaneously: first, the translation from an Indo-European language into a Western Malayo-Polynesian (WMP) idiom, and second, the exegesis (or reconfiguration) of Indic material and its refitting into a familiar/known cultural context, within the "horizon of expectations « of both the producers and consumers of literature.

In this article we present key instances of such "cultural translations " as attested in texts composed at different times and in different geographical and religio-cultural milieus, and try to sketch a preliminary taxonomy of their formal features. Our aim is to document how local agents (re-)interpreted, fractured, and re-stated the message conveyed by the Sanskrit verses in the light of their contingent socio-cultural contexts, agendas, horizons of expectations, and prevalent exegetical practices. Our underlying hypothesis is that local milieus of textual production underwent a progressive »drift" from the Indic-derived scholastic traditions that inspired - and entered into a conversation with - the earliest sources, composed in Central Java in the Early Medieval period, and progressively shifted towards a more embedded mode of production in East Java and Bali from the eleventh to the fifteenth century and beyond. ${ }^{5}$ While these two poles in the discourse can be situated within the theoretical and chronological parameters of the socio-linguistic phenomena of the "Sanskrit Cosmopolis « and "Vernacular Millennium « formulated by Pollock, ${ }^{6}$ some fine-tuning is needed to do full justice to the dynamics of cultural-religious and linguistic transfer at play, in particular by engaging with the textual genre of tutur/tattva, which was completely passed over in silence by Pollock, and which has received remarkably little scholarly attention thus far. ${ }^{7}$

In the later tuturs, and even more so in the parvas, one often has the impression that the Sanskrit text is a mere "pretext« to authorize statements that are local in character, i.e. can be situated within a local context of understanding and practice.

6 Pollock, Language of the Gods.

7 On this class of texts, see Acri, Sanskrit-Old Javanese tutur literature, and Dharma Pātañjala. 
Old Malay and Old Javanese in a Comparative Perspective:

From "Connecting" to "Zone-shaping" Forms of Literature

During the medieval period, the Malay-Indonesian archipelago was an active player among the transcultural societies of the Sanskrit Cosmopolis. One of the first visible products of the interaction of South Asian and indigenous linguistic and cultural practices is the languages of inscriptions that were developed through combining Sanskrit figures, tropes, metres and vocabulary with an underlying base in a language of the WMP group. Three of these - Old Malay, Old Javanese, and Old Balinese - left a significant inscriptional record and one - Old Javanese - developed very early into a literary language active for over a millennium that even today has its practitioners among Balinese students of the language they call Kawi, the language of poets.

The inscriptional record and premodern literature in Old Javanese show us that we must always take into account the language order of the premodern archipelago in our assessments of textual and inscriptional evidence. This means observing the formal differences in structure and diction between texts of the theological, didactic and prose traditions on the one hand, and the poetic traditions of the kakavin and kidun literatures on the other. ${ }^{8}$

In the prose traditions we will find an approach to text-building that harks back to Sanskrit models of the commentary, but adapted to the needs of translation within a pedagogy that in its first phase of development depended on bilingual preceptors capable of translation from Sanskrit into a local idiom in the process of development as a literary idiom, a Prakrit to the Sanskrit sources. At this stage Old Javanese served as the idiom of what Braginsky ${ }^{9}$ has called a "connecting literature, « a literature couched in a local idiom that provides a link to an authoritative source located elsewhere. Both Old Malay and Old Javanese were ideally suited to formulation as higher-order Prakrit languages, since both make use of similar morphology and morpho-syntactic processes that allow for the easy incorporation of "foreign" lexical elements into their WMP-based structures of meaning. As Braginsky has proposed for an "invisible« early literature in Malay, it may be that we should look to the religious institutions of the Sumatran/Śrivijayan branch of the Śailendra dynasty as the crucible for a "connecting literature " centred on the canon of Sanskrit or Sanskrit-inspired Buddhist works. In this view what we see as a characteristic form of structuring texts in the Old Javanese theological literature was first developed in the Buddhist religious institutions of Sumatra and the Thai-Malay peninsula as a literature that connected the emerging literary awareness of the archipelago with distant centres of cultural production.

8 See further in Hunter, Translation, for the claim of a basic distinction in Old Javanese letters between "poetic « and "commentarial« forms of translation. The term "poetic« might be better understood as "transcreational«.

9 Braginsky, System. 
By contrast, in the belletristic (kakavin) tradition in Old Javanese there appears to be no clear trace of the influence of Sanskrit models of the commentary. We find rather a consciously fashioned literary language, an Old Javanese Prakrit if you will, that was developed to suit the needs of what Braginsky ${ }^{10}$ has termed a "zone-shaping literature «, a fully self-conscious literature produced as an integral part of a major cultural formation. The earliest phase of the development of Old Javanese as a language of literature is represented by the Old Javanese Rämäyana and by the kakavin verses of the Sivagrha inscription of $856 \mathrm{CE}$, which Aichele ${ }^{11}$ has shown was very likely produced »in the same workshop " as the Old Javanese Rämāyana. ${ }^{12}$

In what follows we will be examining several case studies from the early theological and philosophical literature of Java that share a text-building strategy based on Indian models of the commentary. These strategies are used both to structure the text, and to link the text at hand to authoritative originals in the Indian tradition. They are thus kept in view throughout the process of composition. The creative enterprise of kakavin composition, on the other hand, follows Sanskrit standards of creativity that put a high value on innovative language, figures and tropes. The traces to Sanskrit originals are thus largely effaced, even when an Old Javanese work takes one of them as a model.

\section{Morphological Incorporation in the Inscriptional Languages}

The three languages of insular Southeast Asia known for their early inscriptions - Old Balinese, Old Malay and Old Javanese - all share similar morphosyntactic features that allow for the easy incorporation of new, non-native terms into a WMP base. This is still the case in modern Indonesian, where a quick check on the translation of "socialize« yields men-sosialisasi-kan, a perfect illustration of the process of morphological incorporation that makes a stronger bond between loan words and the local base than is ordinarily the case, something closer to the interweaving of Sanskrit and local elements developed in the »jewel and coral« (manipravalam) languages of Kerala and Tamilnadu.

As the case studies in this chapter will show, processes of morphological incorporation and juxtaposition of imported and local lexemes prominent in the inscriptional languages are also basic to the mode of composition found in the early theological literature in Old Javanese. It will thus be useful to review two examples of the intermingling of Sanskrit and local elements as found in an Old Javanese inscription dated $860 \mathrm{CE} .{ }^{13}$ This will serve as a prelude to the first level of analysis of the case studies from the Old Javanese doctrinal and soteriological literature.

Ya ta susukən dharmasima ləpas denira pāduka mpuniku in Bodhimimba sìma kaliliranani vkanira Dyah Imbani Dyah Anärgha sambandha sira pāduka mpunku in Boddhimimba mahāpurușa kșatriyakula boddhalakșaṇa prasiddha Vairocanātmaka guru pañajyannira pāduka Śri Mahārāja sira [...] sira pāduka mpuñku i Bodhimimba sarisaryy akāyakāya makarahinanivini ayoga amüjāsamādhi ajapāmrārthanakən ri kajayaśatrvan Śri Mahārāja.

10 Braginsky, System.

11 Aichele, Vergessene Metaphoren.

12 See also Acri, On birds.

13 Copper plates of Kañcana, dated 782 Śaka (860 CE). From the plates of 1295 Śaka (1367 CE) republishing two earlier charters. See Sarkar, Corpus 1, 133 for an alternative date of the original as 794 Śaka (872 CE). 
These (rice-lands) then should be marked out as a free dharma-freehold by the reverend gentleman of Bodhimimba. The freehold is to be inherited by his children Dyah Imbani and Dyah Anärgha the occasion being that the reverend gentleman of Bodhimimba is a great soul, born of a noble lineage, having the characteristics of a follower of Buddha, successful [in attaining] self-identification with Vairocana, and the teacher of holy knowledge to his majesty the king. He, the reverend gentleman of Bodhimimba each day makes every effort, day and night, to perform yoga, to make offering-prayers, to engage in spiritual concentration, to recite mantras [and] to pray earnestly for the victory of his majesty the king over his enemies.

This text has clearly been drafted by a learned hand, moreover one who is Buddhist and very likely a follower of an esoteric school based on the mandala of the transcendental Buddha Vairocana. In this excerpt, as is the case throughout the later history of Old Javanese, cases of incorporation into the Old Javanese morphosyntactic base are not uncommon. The most prominent examples are the verbal derivation amrärthanakan, "to pray for «, based on Sanskrit prärthana, "prayer, supplication " with the addition of Old Javanese verbal affixes $a N$ - and -akan and the following nominal derivation ka-jaya-śatrv-an, »the state of victory over enemies" based on Sanskrit jaya-śatru, victorious over enemies.

Here we see a common pattern of accommodation across two linguistic systems, one contributing new lexical material and meanings drawn from a higher-status, cosmopolitan language, the other an indigenous linguistic base that provides a matrix for the development of what are essentially new, literized languages with a special role to play in the religious and political life of their speech communities.

\section{Vyākhyā: Methodology and Aims}

In this section we begin to examine representative texts from the didactic and narrative traditions of Old Javanese from the point of view of their possible relationship with "forms of the commentary" as known from Indian sources. This is not to suggest that Old Javanese sources are simply translations or mirror images of South Asian textual sources, or to imply that Old Javanese materials might stand in a secondary relationship to Sanskrit sources. It is rather to suggest that there may be formal correspondences between the structuring of didactic and narrative materials in the Old Javanese and Sanskrit traditions, and, if this is the case, similar correspondences may be found in the sphere of pedagogy and the organization of curricula in the religious institutions central to cultures with a long exposure to Indian religious ideas and practices.

Noting some initial similarities between works of the Old Javanese didactic tradition and commentaries like those of Jayamangala and Mallinātha, we propose that the term vyākhyā, "exposition, commentary", might be adopted as a device for measuring the degree to which Old Javanese textual sources recapitulate the form taken by Indian commentaries in the transmission of knowledge and organization of a pedagogy. Here, vyākhya is used as a term to mean an expository reading of a parent text that takes the form of a phrase-by-phrase glossing of the text, with the addition, where needed, of grammatical materials based on Pāninian analysis. 


\section{An Old Javanese Commentary on the Jānakiharaṇa of Kumāradāsa}

When initiating a study of the role of Indian forms of the commentary in the Old Javanese tradition we are faced immediately with many difficulties. The first is that precious few documents have been preserved that bear traces of a tradition of teaching Sanskrit in the context of a guru-sisyya transmission and with the use of a commentary. Fortunately, at least one fragmentary text has surfaced that has provided material evidence for just this mode of transmission. This is a fragment of what appears to be a student's "class notes" on a rendition of Kumāradāsa's classic Jānakihharaṇa. ${ }^{14}$ This fragment shows Old Javanese being used to provide a phrase-by-phrase gloss of the original, with at least one point where a lexeme from a commentary on the Jannakiharana has been included in the text, thus suggesting that the Sanskrit original was taught along with expository materials in both Sanskrit and Old Javanese. In the Old Javanese gloss on Jänakiharana I.2c we can observe the process of »classroom study « that is recorded in the textual artefact: ${ }^{15}$

akhandamāno manujeśvarānām mānyo manojñaih gunajaih gunajñahakhanda na. tan apiyak māno na. kāhānkāranira manujeśvarānāìn na. san ratu mänyo na. pinūjanira manojñaih na. konanunan guṇajaịh na. kaśaktyan, guṇajñah ṅa. vruh in guṇa. sambah-nin hulun mañgalani majarakna mahāmaramālā prākṛta // 1.1

akhanda means "not taking sides, not split«, māno means "his sense of self«, manujeśvarānām means "the lord king", mänyo means "his being praised", manojñaih means "to be longed for", gunajaih means "the state of being powerful«, gunajñah means »he understands good qualities."

Fragmentary though it may be, the text recording lessons in the Janakiharana with Old Javanese glosses gives us positive evidence for a pedagogy based on transmission of root texts along with a commentary and the phrase-by-phrase glossing of the original typical of the Indian vyākhyā.

15 Lokesh Chandra (Sanskrit studies, 1) notes a verse from the Jänakiharana that is found in the "eclectic [Old Javanese] collection « Svarasaminitā. This led to his search of Krtabhāṣā lontars, which resulted in finding that manuscript Leiden Cod. Or. 5089 in that collection contains what can best be described as classroom notes for the study of the Jānakiharaña, a kāvya of the sixth-century poet Kumāradāsa. 


\section{Case Study I: The Old Javanese Lexicographical Work Amaramālā}

We begin the review of case studies in this article with the Old Javanese lexicographical work Amaramāla.$^{16}$ There are several reasons for choosing this as the first work to be examined. First, if $\mathrm{Krom}^{17}$ is correct in assigning this work to the mid-eighth century CE based on its dedication to the Śailendra monarch named Jitendra, then it is among the first works that give evidence of literary activity in Old Javanese. Indeed, since the Sukabumi inscription of Śaka 726 (804 CE) has to date been considered the oldest evidence for the existence of Old Javanese, it could predate even that inscription. ${ }^{18}$

In making an assessment of the nature of the Amaramālā we should clearly not discount its opening verses, which are quite explicit in referring to Jitendra as »the bull of the Śailendra dynasty (śailendrānvayapungava). While the question of whether or not the Śailendras were of Malay origin is still controversial, there are many reasons to suppose that at the very least the Buddhist "preceptors of the Śailendra kings " (śailendraräjagurubhiḩ) noted in the Kalasan inscription can be understood in terms of a close relationship between Buddhist institutions of Sumatra and Central Java during the period c. 700-850 CE. ${ }^{19}$

The Old Javanese Amaramāla is characterized in its opening passages as a "Prakritization " of a Sanskrit work, which we can surmise must have been a lexicographical work like the Amarakośa of Amarasimha. Such works were intended to serve as tools in the composition of kāvya, and by the time of Amarasimha (c. $600 \mathrm{CE}$ ) had become an indispensable part of a writer's toolkit. ${ }^{20}$ The opening line of the Amaramāla thus stands at the beginning of a long tradition of referring to works in Old Javanese literary form with the term präkrta, in this referring to works composed in a literary language fashioned on the order of Sanskrit:

\section{sambahnin hulun mañgalani majarakna mahāmaramālā prākrta // $1.1 / /$}

"My offering with a bow of homage is an auspicious benediction for making an exposition of the great Amaramālā in Prakrit form. $\ll^{21}$

The Amaramāla is part of the larger and composite text entitled Candrakiraṇa, edited as Chandakarana by Lokesh Chandra (Chanda-Karana). Here we have followed the text reconstructed by Lokesh Chandra in his edition, without systematically reporting deviations (whether in the main text or in the apparatus) from the original West Javanese gebang manuscript L631, except when we have proposed new emendations on the basis of the actual readings of the manuscript.

17 Krom, Hindoe-Javaansche Geschiedenis, 145-146.

18 See Zoetmulder (Kalangwan, 3) on the Sukabumi inscription.

19 See Sarkar (Corpus, 36-40) for a text and translation of the Kalasan inscription. See Jordaan and Colless, Mahäräjas, for a recent review of the long controversy surrounding the origins and nature of the Śailendra dynasty. Nihom's noting (Studies, 114) the verifiable presence of the mandala systems of the Jagadvinaya, Trailokyavijaya and Sarvadurgatipariśodhana in Old Javanese textual sources supports a close relationship of Śrivijaya and the Śailendras of Java. As he points out, the presence of these mandala systems suggests that »the initial importation of yogatantra systems into the Archipelago most likely took place no later than the end of the seventh century [...] This would seem to put us in Śrī Vijaya." Since the Sumatran branch of the Śailendra line of kings is believed to have »retreated" from Java by c. $856 \mathrm{CE}$, this would give us a terminus pro quem for at least the core sections of the Amaramälä.

20 Lokesh Chandra (Chanda-Karaṇa, 144) surmises that the Old Javanese Amaramālā is based on a section of a nowlost Indian work by that name, supporting his claim by citing references to a text by that name in Kșirasvāmin's commentary on the Amarakośa and Hemacandra's commentary on another lexicographical work, the Abhidānacintämaṇi. See Raj Pant, Jațarūpa's Commentary, for an authoritative work on the Amarakośa that focuses on Jațarūpa's commentary, the Amarakośatilaka, likely composed in the second half of the tenth century CE.

21 "My offering with a bow of homage«: it was a common trope in Old Javanese to refer metonymously to what one offers up to a superior as one's sambah, or »bow of respect«. 
We turn now to the form taken by the opening passage of the Amaramāla. This section of the text is crucial to this study in that it may represent the earliest stage of a »translational « form of composition and pedagogy for which we have written records, and because it bears the unmistakable imprint of a commentarial form of rhetorical organization. The development of Old Javanese into a literary language during the eighth and ninth centuries CE follows upon similar processes that are observable for Old Malay in five inscriptions of seventh-century Sumatra issued by Śrī Jayanāśa/Jayanāga. In the Amaramālā we begin to see evidence for a "commentarial« form of composition that appears to be the textual record of pedagogical practices that were initiated in the Buddhist institutions of the western Malay-Indonesian archipelago and made their way to Java by way of a close relationship of the "Javanese branch" of the Śailendra dynasty with a Buddhist polity of the western archipelago known to history as Srivijaya. From this perspective the precise political form that may have been taken by this relationship may not be as important as the question of the emergence of a commentarial form of text-building that from the time of the Amaramāla onward was developed in parallel fashion in both Hindu and Buddhist streams of Javano-Balinese religious and philosophical literature.

The evidence of the Amaramāla is critical to this study because it introduces two modes of text-building that have had a lasting impact on the prose traditions of Java and Bali. The first of these is a "dyadic technique. " In this form of composition the text is built up in paired Sanskrit verses and their Old Javanese exegeses, with the logic of the didactic narrative following the order of verses in the Sanskrit original, but with a great deal of flexibility in terms of the content of the exegeses. The initial dedicatory stanza of the Amaramāla is a good example of this type of composition:

\section{Sanskrit śloka:}

śivai் sarvagatam śāntam / sarvajñam sarvadam gurum ${ }^{22}$ / praṇamyāmaramāleyai் / nāmalingà̇ nigadyate //

"Having bowed down to Śiva - the all-pervading, peaceful, omniscient, all-bestowing teacher - I will recite the Amaramālā, [and expound] nouns and [their] genders."

Old Javanese glosses:

bhațāreśvara sira sambahin hulun / lvirnira: ${ }^{23}$

»My bow of homage is to the god İ́vara. His form is:«

sarvagatam் vyāpaka rin bha / śāntam jitendriya ta sira / rin sarvajña ${ }^{24}$ amratyakṣākən ta sirātītānāgatavartamāna mvan̉ sūkșma [h]atisūkșma / sarvada $\dot{m}^{25}$ aveh anugraha ri bhakti ri sira / sira gurunin sarvadevatā /

Em.; sarvvatigurum ms.; sarvādhigurum ed.

23 While this phrase occurs without overt reference to a Sanskrit lexeme in the original, there is no doubt that it responds to śivam in the Sanskrit śloka.

24 Em.; sarvajñana ms.; sarvajñāna ed.

25 Em.; sarvādi ed.; sarvāddhi / ms. Our proposed reconstruction is supported by the fact that most of the forms

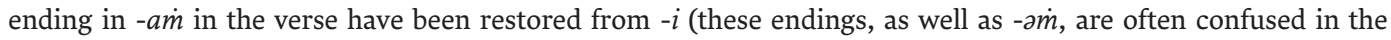
Sanskrit portions found in Javanese manuscripts), as well as the Old Javanese gloss. 
"sarvagatam [means] pervading space; śäntam [means] he has mastered the senses; in regard to sarvajña, he sees clearly the past, future and present and the subtlety of the most subtle; sarvadaim [means] that he gives favour to all those who are devoted to him; he is the guru of all the gods."

uvus pva ìhulun sumambah ri sira / ajaraknanin hulun tikin mahāmaramālà ${ }^{26}$ pintonaknain abhidhāna mvaì linga //

»Having completed my homage to Him, I will expound this Mahāmaramālā, [and] demonstrate the nouns and their genders."

In the Old Javanese glosses there is a shifting back and forth here between Sanskrit lexemes or phrases and their glosses that follows the classical vyākhyā form to the letter, except that the explanatory phrases are given in Old Javanese, which is often enriched with Sanskrit lexemes. And it is clear that the composer of the Amaramāla has made an effort to account for the full content of the original, for example explaining the Sanskrit passive form nigadyate with the Old Javanese ajaraknanin hulun, and nämalingam, "nouns and their genders, " with Old Javanese pintonakanan் abhidhāna mvan் linga, "apellations (i.e., nouns) and their genders will be demonstrated «, thereby supplying another Old Javanese passive verbal form for the sake of clarity. ${ }^{27}$

In a longer section following the introductory verse we find a panegyric to the royal patron of the work that is composed in the fashion of a commentary in vyākhyā form, with a series of Sanskrit phrases introduced that are followed by Old Javanese glosses. These passages need not expand on a particular verse in the work but can introduce new material directly.

hana sira ratu pinakacū ầmaṇi denin sāmantajagatpālaka ${ }^{28} /$

"There is a king taken as the crest-jewel of all the guardians of the world.»

suragaṇair iștah prajärakṣaṇe ${ }^{29}$ inarəmbha denin vatək devatā / rumakṣa prajāmaṇụala /

"suragaṇair iștah prajārakṣaṇe: prepared by the company of gods to protect the realm and its subjects,"

26 Em.; mamaramālā ms.; amaramālā ed.

27 It should be mentioned here that another title under which Amarasimha's Amarakośa - a Sanskrit lexicon probably related to the Amaramālā - was known is Nämalingānuśäsana, »The teaching about the gender of nouns".

28 Lokesh Chandra emends samantajagatphalaka into sämantajagatpālakah, but we find the insertion of the visarga of the Sanskrit nominative unnecessary here as the compound has been embedded directly into the Old Javanese (prefixed by denin, which would render the Sanskrit instrumental case) and does not represent, strictly speaking, a direct quotation. Cf. the analogous case in fn. 30 below (and contrast the other Sanskrit forms in the passage, such as vidyāvadätottamah, sädhujanapriyah, kulasyäntakah, etc., which do have visargas in the original and are enclosed between punctuation marks).

29 The ms. actually reads prajärakșaṇeh, therefore prajärakṣane in the edition represents an emendation by Lokesh Chandra. 
apayan yogadhyānasamādhikarmakuśala ${ }^{30}$ sira / vidagdha ri kagavayanin yoga dhyāna samädhi /

"For yogadhyānasamädhikarmakuśala: he is wise in the performance of yoga, dhyā$n a$ and samādhi.«

vidyāvadātottamah / sira ta viśeșanin mahāpuruṣa śāstrajña / nișthāniran samañkana kottamanira / ndan tah upaśama ta sira /

"vidyāvadātottamah: He is exceptional among the great men who are knowers of the Sāstras. His lowest ebb is at once his highest, and yet he is self-controlled."

sādhujanapriyaḥ / anurāga ta sira / ri sakveh sañ sādhujana /

»sādhujanapriyah: He is beloved by all good men."

śatrūṇām kulasyāntakaḥ / mañkana sakvehnikan śatru bāhyābhyantara / sampun inarișțakənira /

"śatrūnām kulasyāntakah: Likewise, all of his enemies, whether internal or external, have been completely annihilated by him. « $^{31}$

śailendrānvayapun்gavaḥ / sira ta pinakatunganin śailendravamía /

»śailendrānvayapungavah: He is regarded as the bull of the Śailendra dynasty.»

jayati [h]amnən் ta sira /

»jayati: He is victorious."

śrīmahārāja samañkanātiśayanira / sira ta śrī mahārāja jitendra samjiñanira // 1

"His being an illustrious Mahārāja is the reason for his present renown. He is the great King Jitendra by name.«

In the Amaramāla we find a good illustration of the appropriation of the vyākhya form of Indian commentaries for the needs of translation in a pedagogy and connecting literature that linked Śailendra Buddhist institutions to the wider Asian Buddhist world through the trading, diplomatic, and religious networks of the western Malay-Indonesian archipelago. As we will see in examples from the early theological literature, the textual use of the vyākhya technique appears to reflect a pedagogical practice that was further refined in the textual tradition following the Amaramālā.

30 Lokesh Chandra emends ${ }^{\circ}$ kuśala into ${ }^{\circ}$ uśalah.

31 There has been an interesting shift in meaning here: Sanskrit śatrünäm kulasyäntakah means »he who is the destroyer of the families of his enemies. "But the Old Javanese gloss turns its attention to beliefs well known in the Javano-Balinese tradition that conquering one's »internal enemies« is the key to success in the struggle for political survival. 
Case Study II: The Sañ Hyañ Kamahāyānan Mantranaya

If we look now at an early work from the Mahāyāna Buddhist literature, the Mantra System

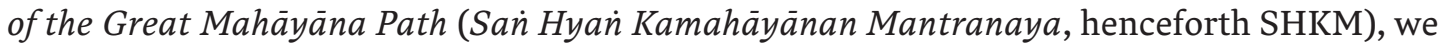
find the same use of the vyākhya form of glossing that is prominent in the Amaramālà. And we find the same use of a dyadic technique based on the juxtaposition of Sanskrit verses with blocks of Old Javanese glosses. The difference is that the dyadic form of composition was only occasionally used in the Amaramālā, but has become standard practice in the SHKM.

There has been some debate about the dating of this work. Goris ${ }^{32}$ proposed that it be dated to the tenth century, for Version "C « of the text, as per Kats' identification, contains a colophon mentioning the name Mpu Siṇdok of the İsāna dynasty (r. 929-947 CE). However, this is apparently a Śaivized text that might have been composed later than the other two purely Buddhist texts in the same manuscript. In 1974 de Jong summarized the findings of the Japanese scholars Wogihara Unrai and Sakai Shiro, who had shown that the Sanskrit portions of the SHKM can be traced to the Chinese version of the Mahävairocanasütra and to Chinese and Tibetan versions of the Adhyardhaśatikāprajñäpäramitāsūtra. ${ }^{33}$ More recent scholarly work has also identified such Sanskrit sources as the commentarial literature on the Guhyasamajja, ${ }^{34}$ as well as other esoteric manuals such as the Sarvavajrodaya. ${ }^{35}$ These considerations suggest that the doctrinal basis of the SHKM was well known in Java by at least the ninth century, and that the composition of the text could easily have taken place in that period or not long afterward.

In an example of this form of dyadic composition, SHKM verse 31, we are witness to an exposition of a practical perspective on the practice of austerities that suggests a long history of initiatory practices in both Hindu and Buddhist circles in the archipelago: Chinese between 724-725 C.E. by Śubhakara and Yijing (de Jong, Notes, 633-635). Archaeologist John Miksic (Borobudur, 23) in turn notes that the Mahāvairocanasūtra "was probably found in most monastic libraries in Java and Sumatra during the ninth century«.

Goris, Bijdragen, 151.

Kandahjaya, San் Hyan் Kamahāyānikan, 70, 72.

Ishii, Correlation, Table 2. 
svam ätmānam parityajya tapobhir na ca pīdayet ${ }^{36} /$

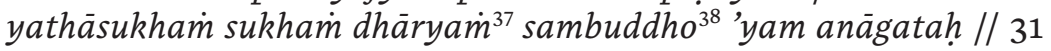

ka: / pativar ikāvakta ${ }^{39}$ / svakāyanirapekṣatah kita hayva trọ̣na rin avak / tapobhir na ca pidayet $t^{40}$ / hayva pinirsakitan ${ }^{41}$ rin tapa / hayva vineh gumavayakən kavənannya /

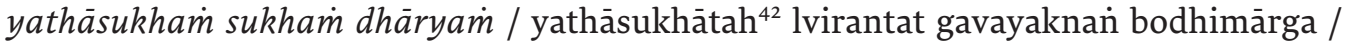
sambuddho 'yam anāgataḥ / hayva gyā hyañ buddha kita dlāha /

Having given up one's own Self, one should not oppress [oneself] with acts of penance. One should follow pleasure, comfortably, for he is a future Awakened one.

"The meaning is: you should abandon your body to its fate; you are svakāyanirapekșa, you should have no attachment to the body; tapobhir na ca pidayet: don't torture it with austerities; don't allow them to take power over you; yathāsukhaim sukham dhäryaim: as you carry forward the way to enlightenment the path you take should be one of ease; sambuddho'yam anägatah: don't rush; you [will become] the Lord Buddha in the future. $«^{43}$

An analysis of the Old Javanese passage shows that, in common with the initial stanzas of the Amaramāla , the vyākhy $\bar{a}$ form of commentary has had a shaping effect on how "translation" was conceived of in the production of the SHKM. The Old Javanese commentary does not directly render the Sanskrit into Old Javanese following the vyākhyā form, but instead repeats each of the four Sanskrit pädas and glosses them into Old Javanese.

First, the Old Javanese phrases that translate päda (a) of SHKM verse 37 begin with an imperative form (pativar ikâvakta, "abandon your body to its fate«). This suggests that the text was used as an active guide for imparting the particular steps of an initiation, a fact that is not always brought out explicitly in the Sanskrit verses of the SHKM. ${ }^{44}$ The translation then moves on to a paired Sanskrit-Old Javanese phrase that expands on this theme by introducing a Sanskrit synonym and its gloss. Here the Sanskrit synonym introduced by the composer of the Old Javanese commentary (svakāyanirapekșa, »one who takes no notice of one's own body«) suggests an easy familiarity with the essentials of the technique of

36 Em.; nnnah tha pidayet ms., nätipidayet em. Kats, Wulff. The text has been reconstructed on the basis of the numerous Sanskrit parallels (viz. Dīpanikarabhadra, Guhyasamäjamaṇdalavidhi, ed. Klein-Schwind, 384b; Hevajrasekaprakriyā, ed. Finot, 27; Sarvabuddhasamāyoga, ed. Negī, 6.64b, Kriyāsañgrahapañjïkā, ed. Tanemura, 6-6-6-2, verse 22, etc.).

37 Em. Kats (silent); dhäryya ms.

38 sambuddho 'yam ms., Speyer, sambuddheyam Kats.

39 Thus the ms.; prativārikāvakta em. Kats, pațavarikāvakta em. Wulff.

40 Cf. above, fn. 36.

41 Pini[r]sakitan Kats, pinrisakitan em. Wulff.

42 yathāsukhātah em., yathāsukatāh Kats.

43 This excerpt from the SHKM has previously been published as an example of a passage on the practice of yoga in a short study of the Old Javanese Bhịsmaparva by Hunter, Bhagavad-Gītā sections, 192-193.

44 Based on his study of Sakai's work, de Jong (Notes, 621-622) proposed that the textual antecedents of the SHKM related to "four kinds of consecration (abhiseka) associated with the anuttarayoga texts", thus underlining the initiatory aspect of works like the SHKM and Sañ Hyan் Kamahāyānikan. 
creating well-formed Sanskrit nominal compounds (samāsa). ${ }^{45}$ Second, the introduction of certain explanatory phrases in the SHKM suggests the development of an indigenous school of thought that has been brought to bear in glossing Sanskrit originals.

In the second $p \bar{a} d a$, it may not be accidental that an Old Javanese verb phrase (pinirsakitan "be made to be in pain «) has been chosen in that its morphosyntactic form to some degree mirrors the complexity of the Sanskrit optative pidayet.

In vyākhyā form, the third pāda of the Sanskrit śloka is repeated, along with an Old Javanese gloss that to our mind is more clearly worded than the somewhat elusive phrasing of the Sanskrit. The syntax of the Old Javanese is quite alien to Indo-European forms of construction: lvir- $a-n t a$, "your form should be « is an irrealis form based on a nominal root, with the addition of a second person pronominal clitic (-nta), while t'gavayakna is an irrealis form, here with optative force. ${ }^{46}$

Once we consider the details of Old Javanese syntax, the phrasing of the gloss reads with a precision that suggests principles of brevity and clarity well known from the South Asian śástrìya tradition, and may indicate an inclination among Javanese composers to seek a similar form of precision in their own idiom. It is clear that in formal terms there is a great deal of similarity with the "vyākhyā style« of the Amaramālā: for instance, we can see a similar tendency to combine the Sanskrit-Old Javanese vyākhyā style with direct translation of parts of the śloka, either in mixed Sanskrit-Old Javanese or in Old Javanese. Note that the SHKM pattern follows that of the Amaramālā, but is, if anything, more conservative in that it retains the Sanskrit-Old Javanese vyākhyā format for all of the four pādas (b-d), where the Amaramāla switches to direct translation in (c-d). In conclusion, it can be said that the SHKM takes up the commentarial style of Prakritization proposed in the Amaramāla and carries it forward in the service of the didactic needs of the Buddhist institutions of ancient Java, apparently in terms of practices of initiation.

\section{Case Study III: The Vrhaspatitattva}

Like many other works from the Old Javanese didactic tradition, the Śaiva speculative and soteriological text Vrhaspatitattva provides us with no firm internal evidence that could be used to establish its date of composition. In cases like these we have to rely on the more circumstantial evidence of the contents of the text, their possible relationship with other texts in the corpus, and with antecedent textual materials from South Asia - namely, the body of early Śaiva Siddhāntatantras, alongside Sān̉khya and Pāśupata sources. A number of scholars have previously sketched some of the doctrinal characteristics of the Vrhaspatitattva, and argued that this text, along with a handful of other texts of the tattva genre, may be regarded as precursors of the (mature) Sanskrit Śaiva Saiddhāntika scriptures, which started to develop in India from the sixth century onwards. ${ }^{47}$ Acri ${ }^{48}$ has advanced a solution to the problem of the identification of the term Alepaka found among three terms referring to sectarian orientations in Vrhaspatitattva 2.3-4 and 3.37, viz. Śaiva, Pāśupata, Alepaka. This reference

45 A recent contribution by Radicchi (More on the Kärakasamgraha) has demonstrated the emphasis found in the Javano-Balinese tradition on the correct formation of samäsa. Important passages on this subject can be found in Old Javanese works like the Kärakasamissepa and the Kärakasamgraha.

46 See Oglobin, Irrealis, 3 for a brief review of the use of the second person proclitic form $t$ ' in the formation of one type of imperative construction. See also Hunter, Yati, 11.

47 Zieseniss, Studien, 4.

48 Acri, Vaimala sect. 
had previously been assumed to parallel later references to the three major religious sects of East Java, the well-known Śaiva-Sogata-Rssi. While the Vrhaspatitattva term Pāśspata can be linked to the term Rosi, efforts to link the Alepaka with some form of Buddhism have fallen far short of being satisfactory. Drawing on Sanskrit sources, Acri has noted that the term Alepaka is synonymous with Vaimala, an early Atimārga sect within Śaivism, which may have broken off from the Pāśupatas at an early date.

The reference to the Alepaka sect represents a crucial point in the history of religion in premodern Java. The triad Saiva-Pāśupata-Alepaka suggests that the Vrhaspatitattva may have been composed at a time when Buddhist institutions of East Java had yet to gain enough importance to be accepted as a major sectarian division within the larger grouping of religious institutions. We know that Buddhist institutions were supported by the Kadiri kings beginning with Airlanga and gained greater prominence during the Singhasari dynasty (1222-1293 CE). Their presence as a major element in the configuration of religious domains was formalized, and listed with precise detail, in fourteenth century works of the Majapahit dynasty like the Deśavarnana. But the evidence of the Vrhaspatitattva suggests that at the time of its composition the author(s) recognized two currents representing the Atimarga forms of Śaivism, as opposed to a third - and possibly predominant current - representing a Javanese mainstream form of Mantramārga Śaivism akin to the Indian Śaivasiddhānta.

When we look closely at the Vrhaspatitattva we find that the dyadic presentation of Sanskrit verses and Old Javanese glosses is very much in evidence. However, among the glosses we find both simpler exegeses that follow the phrase-by-phrase presentation of the vyākhya model, and more complex cases that often represent fully developed doctrinal presentations:

\section{bhagavan deva devānām anādiparameśvara /

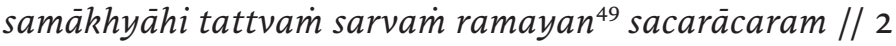

sājñā bhațāra / kasihana rānak bhațāra / varahən ika sañ hyañ aji kabeh / matañnyan akveh prabhedanira de bhațāra / an pavarah ri sañ vatək devatā kabeh / hana Śaiva naranya / hana Pāśupata naranya / hana Alepaka niaranya / ika ta kabeh / kapva dudū / pavarah bhațāra sovañsovañ / lavan ikañ śāstra vih akveh ata prakāranya / ndya ta kalinanika / matannyan vineh makveha / ikanañ mārga kalavan aji de bhațāra / mañkana lin bhagavān Ṿ̣haspati //

Oh Lord, God of Gods, Supreme Lord without beginning, may you relate to me (the truth about) all the elements of existence, both moving and unmoving.

"O Lord, please be kind to your son, teach me the reverend sacred lore in its entirety, [and] the reason why there are many different forms of it, as it is taught to the assembly of the gods. There is what is called Śaiva, there is what is called Päśupata, there is what is called Alepaka. All of them, they are equally different teachings of the Lord, one by one. And also, there are many classes of scriptures. What is the meaning of this, [and] the reason why so many religious paths and scriptures have been allowed by the Lord?»

49 Sudarshana Devi (Wrhaspati-tattwa »Text with notes« section, 11) has noted the difficulties of the reading of the fourth hemistich from the various mss. and that her emendation to ramayan may not be entirely apposite. 
The analysis of the Old Javanese passage reveals a text-building strategy that does not depend on a vyākhya form of composition, but rather represents the "pure dyadic « form. The passage forms a loosely structured unit with the opening śloka, but in terms of meaning does not necessarily relate to it on a one-to-one basis.

In the opening clause (sājña bhațâra / kasihana rānak bhațāra), the phrasing corresponds roughly to the string of vocatives filling the first two hemistiches of the Sanskrit verse (bhagavan deva devānām anādiparameśvara), but does not represent so much a translation or gloss on the Sanskrit as a paralleling of the Sanskrit vocatives with phrasing that is wellknown from the entire tradition of prose works in Old Javanese, and is, indeed, retained in the special Old Javanese-derived language of the Balinese shadow theatre (wayang).

The clause varahon ika san hyan aji kabeh glosses the Sanskrit samākhyāhi tattvam sar$v a m$, but replaces the tattva "principles of reality" of the Sanskrit passage with the Old Javanese phrase san hyan aji kabeh, "the reverend sacred lore in its entirety." This could be due to the fact that tattva in Old Javanese could signify a "sacred text on metaphysics".

In the lines that follow thereupon, there is still some link with the Sanskrit śloka in that the phrase akveh prabhedanira, "there are many different forms of them «, can be said to be related to the element of contrastive plurality in the phrase sacarācaram, "those that are ambulatory, and those that are not « (i.e., animate and inanimate entities); the Old Javanese cannot be considered a direct gloss on the Sanskrit, but rather continues the line of development that was initiated in verse 2. In the clause starting with hana śaiva [...], there is no longer any direct connection between the śloka and the Old Javanese. Instead the composer has introduced a discussion of three sectarian divisions within Śaivism that appear to be an entirely Śaivite form of the "three denominations" (tripakșa) known from East Javanese textual sources from as early as the composition of the kakavin Bharratayuddha (c. 1135-1157 $\mathrm{CE}$ ). The discussion is continued, with a final appeal to the deity that recalls the imperative phrase of the Sanskrit (samākhyāhi tattvam sarvam). The closing statement, marikana lin bhagavān Vrhaspati, has no parallel in the Sanskrit. The śloka and its "dyadic" counterpart in the Old Javanese are thus set into the framework of a tantra- or purāna-like narrative that reproduces a doctrinal discussion in the form of a conversation between a sage and the deity.

Verse 15 of the Vrhaspatitattva gives us a good example of the continuing use of the $v y$ $\bar{a} k h y \bar{a}$ form of glossing in this early work of Javanese Śaivism:

laghu prakāśakam sattvaì cañcalam tu rajah sthitam /

tamo guru varanakam ity etac cittalakșanam // 15 //

ikań citta mahanan māva / yeka sattva naranya / ikan் madərəs molah / yeka rajah naranya / ikan் abvat pətən் / yeka tamah naranya //

Sattva is light and brilliant, while rajas is dynamic. Tamas is heavy and concealing. Such are the characteristics of the intellect.

"The intellect that is light and brightly shining, that is called sattva. That which moves in a rushing flow, that is called rajah. That which is heavy and dark, that is called tamah«.

The Vrhaspatitattva thus documents two exegetical strategies, both in a Sanskrit-Old Javanese dyadic form: one that considerably expands on the themes of the Sanskrit verses (such as verse 35), and one that follows more closely the vyākhyā style encountered in the Amaramālā and SHKM. 


\section{Case Study IV: The Jñānasiddhānta}

The Jñanasiddhānta is a tutur organized in the form of Sanskrit-Old Javanese translation dyads, consisting in a core - also preserved independently as Tutur Kamokșan - complemented by Old Javanese prose opening chapters. This text, of a composite and heterogeneous nature, reveals a later period of compilation and an East Javanese Majapahit milieu and/or its continuation in Bali from the late fifteenth century.$^{50}$ In this context, older material coming from (possibly Central and/or East) Java was assembled and redacted so as to meet the demands of the local audiences.

Jñannasiddhānta chapter 19, bearing the caption San Hyan் Bhedajñāna »The Holy Gnosis of Difference", is made up of seven Sanskrit ślokas followed by an Old Javanese paraphrase and/or exegesis. This short chapter is a telling example of the reconfiguration of Indic elements into a local context of doctrine and yogic praxis. Its doctrinal background is thoroughly Śaiva, yet a few passages (either Sanskrit ślokas or their Old Javanese exegesis) contain echoes of Sānkhya-Yoga views that may be traced to the Sanskrit Yogasūtras and its annexed commentary Yogasūtrabhāṣya (Pätañjalayogaśästra). The presence of certain technical terms indeed points at a different philosophical and yogic tradition than the Śaiva yoga of the six ancillaries (sadangayoga) commonly encountered in the tutur/tattva corpus, and reflects an attempt to reconcile Śaiva theistic yoga with Pātañjala yoga.

A dyadic style featuring a word-by-word commentary - much like those in the Sanskrit tradition - that elaborates on the text in an original way is epitomized in dyad 5. Having been introduced at the end of the Old Javanese exegesis to Sanskrit verse 4 as providing a definition of the gnosis labelled Sañ Hyan Bhedajñāna, this dyad describes the Lord Śiva, the individual soul, and the state of liberation:

\section{sakalah kevalah śuddhah tryavasthah puruṣah smrtah / malinatvacittamokșah kalpyate nirmalah śivah // 5 //}

Tiga avasthā ya san் puruṣa rin kaləpasan: hanān sakala, hanān kevala, hanān śuddha. Katuturakəna sirān mańkana: sakala naranya makāvak triguña sira. Kevala naranya atingal pamukti sira. Malinatva naranya papāśanira ${ }^{51}$ mvañ triguna. Manovijñānāvaknira. Suddha naranya patinin manovijñāna. Sakeñ sira māri mamikalpa, śūnyākāra, kaivalya, tan hana gələhgələhnirān pamukti. Sira sinaṅguh nirmalaśiva.

The soul is taught to have three conditions: the one visible in material form, the isolated, and the pure; the freedom of the mind from the condition of impurity is conceived to be the Spotless Siva.

50 Hooykaas, Śaiva Siddhānta, has discussed in detail the textual relationship between the Tutur Ādhyātmika (edited by Soebadio as Jñanasiddhänta), the Tutur Kamokșan, and the Ganapatitattva. This chapter is found, with only slight variations, in Tutur Kamokșan and Ganapatitattva (40-45). Some of its ślokas have parallels in chapter 5 of the Bhuvanakośa.

51 The reading papasah, from the base sah "depart, be separated, come loose (papasah = to be separated, split, be broken; see OJED, 1592), makes no sense in this context, and requires emendation. What the text implies here is clearly that the stained soul is ensnared by the three gunas. Soebadio (Jñannasiddhānta, 211) translated the clause papasahnira mvan triguna as "its connection with the three constituents", yet she did not justify her translation. Thus, the reading papasah may be a corruption of either papāśa or mapāśa, from the Sanskrit pāśa (»fetter«), which would fit well into the Śaiva doctrinal context, but have the disadvantage of not being attested in Old Javanese texts (on the other hand, we would expect the attested forms kapāśa and kapāśan to be followed by denin rather than mvañ: see OJED, 1309). 
Three are the conditions of the soul in the state of liberation: there is the one in which he is visible in material form; there is the one in which he is isolated; there is the one in which he is pure. That [souls] being in such [conditions] will [now] be taught: Visible in material form means that it assumes the form of the three constituents. Isolated means that it has left behind the [condition of] enjoyer. The condition of impurity means that it is fettered by the three constituents. Its body is mental knowledge (manovijñanna). Pure means the end of mental knowledge. Because of that it ceases to produce dualizing thought, [its] appearance is void, [it is] isolated; it has no stain when it is in the state of liberation. It is called the Spotless Siva.

As Acri has pointed out elsewhere, ${ }^{52}$ śloka 5 has a parallel in the Sanskrit Kiranatantra (Vidyāpāda 1.23ab),,$^{53}$ an early scripture of the Śaiva Siddhānta:

\section{kevalah sakalah śuddhas tryavasthah purusah smrtah /} malinatvāc citer mokșah präpyate nirmalàc chivàt //

The soul is taught to have three conditions; [that of] the one without [at least one of the bonds] (kevala), the one with [all three bonds] (sakala), and the pure soul (sud$d h a){ }^{54}$ The liberation of the mind from stain is obtained because of [the will of] the spotless Śiva.

The version of the śloka preserved in the Jñanasiddhānta, as well as the parallels found in other tuturs, all read kalpyate »is conceived « instead of präpyate »is obtained «. ${ }^{55}$ Furthermore, all the ablative endings found in the Kirana version are missing in the versions documented in the Archipelago texts, the third quarter being formed by a single compound and the last one substituting the ablative endings (nirmalāc chivāt) with nominatives. The meaning conveyed in the two versions of the śloka is at variance insofar as the Javano-Balinese one equates the mind freed from stain to the Spotless Siva, whereas the South Asian one implies that liberation of the mind from stain is obtained because of the Spotless Siva - thus alluding to the idea of divine grace that played a role in the process of liberation according to the early Śaivasiddhānta, and which was of even greater importance to the theologians of the of non-dualist Tamil Śaivasiddhānta. ${ }^{56}$

The Sanskrit verse appears to hint at a fundamental doctrinal tenet of the Śaiva Siddhānta, according to which the three conditions of the soul (viz. sakala, kevala, śuddha) depend on the kind of stain it is affected by, e.g. māya, karma, and annava. With regard to this matter there are different views within the Siddhānta, as different scriptures and commentaries

Acri, Sanskrit-Old Javanese tutur literature, 119-120.

53 Intriguingly, the second hemistich is not found in all the ancient Nepalese manuscripts nor in Rāmakaṇtha's commentary (see Goodall, Bhațta Rämakanțha's Commentary, 221, n. 188), but it appears in the later South Indian redactions, such as the Devakoțtai edition, and in the version commented upon by Tryambakaśambhu (who places it after 1.23d, see Goodall, Bhațta Rämakanțh's Commentary, 29). Since some of these redactions may have been compiled even after the twelfth century, we may assume that this verse was borrowed in that form either from a South Indian recension of the Kiraṇa or from another version posterior, or in any event unknown to, Rāmakaṇṭa.

54 The translation of this hemistich is by Goodall, Hindu Scriptures, 345.

55 But some (apparently corrupt) Indian mss. read procyate »is declared« (see Goodall, Bhatța Rāmakanța's Commentary, 29).

56 For a discussion of the doctrinal contents of this śloka in the Kirana, see Brunner, Analyse du Kiranāgama, 313. 
present distinct systematizations. ${ }^{57}$ However, the Old Javanese commentary does not refer to any of these systematizations, and does not mention the different kinds of stain or the categories of beings known as pralayakevala, vijñannakevala, etc., either. ${ }^{8}$ On the other hand, the sakala state is defined as the embodiment of the soul in the three constituents (guna). The condition of impurity means that the soul is not separated from the three gunas. This viewpoint may reflect an either archaic or »local« doctrinal status quo, in which the Saiddhāntika ideas around stain (mala) had not yet been codified, and a Sānkhya-Yoga doctrinal matrix was predominant.

The Old Javanese form pamukti, deriving from the Sanskrit base bhukti (see OJED, p. 269), refers to the condition of enjoyer - in the sense of "experiencer « - of the fruits of actions. According to the Śaivasiddhānta, liberation consists in the freedom of the soul from the condition, caused by stain, of bhoktrtva - i.e. of being the experiencer of karma and its fruits. The concepts of bhoktrtva and kevalatva also feature prominently in the seminal scriptures of Pātañjala Yoga. The afflictions, being present in the mind (manas), are ascribed to the soul (purușa), because it is the enjoyer (bhoktro) of their fruits. Yogasütrabhașya 2.27 and 4.34 define the puruṣa as being in the kevala state when it transcends the three gunas through the buddhi. The condition in which the mind is freed is called cittavimukti. According to Sānkhya-Yoga philosophy, śuddha is the state of the purușa when it does not assume the form of mind (citta), although it knows the mind. This view seems to be echoed in the Old Javanese commentary to śloka 5, which explains the word śuddha as a psychological condition involving the end of dualizing thought intended as mental knowledge (manovijñanna). This results in the isolation of the mind. The appearance of manovijñana in this context is quite intriguing, for it is typically found as a technical term in Buddhist sources, meaning "mind-consciousness «. ${ }^{99}$ Our text thus appears to present a mixture of Śaiva, Sānkhya-Yoga, and Buddhist doctrinal elements, which also feature in the following dyad $6 .^{60}$

The dyads discussed above, and, indeed, the whole chapter 5 of the Jñanasiddhānta, present examples of the vyakhya a style. At the same time, they suggest that the commentator was aware of different streams of Indic religions and philosophies and their scriptural canons, and document his attempt to reconfigure those originally "Indian" elements into a local theology and praxis. The resulting doctrinal and soteriological system may be regarded as a synthesis of theologemes and yogic practices belonging to what were perceived in South Asian Sanskrit sources as distinct orientations, i.e. Śaivism and Sāñkhya/Yoga.

57 See the discussion in Brunner, Analyse du Suprabhedägama, 53: "quand il [i.e. the ätman] pénètre dans le ventre de la māyà et en même temps rencontre (mais comment?) karman, on le qualifie de sakala [...]; śuddha, il devient ce qu'il a toujours été en essence, pur et semblable a Siva: c'est l'état de pureté totale, śuddha avasthā. "See also the scheme in Davis, Ritual, 26.

58 Goodall, Hindu Scriptures, 345 fn. 15.

59 Manovijñana is not listed in OJED, which, on the other hand, lists manovijñ $\bar{a}$ (1105) and hesitantly glosses it as "knowing the mind, versed in spiritual things?"

60 See Acri, Re-configuration. 


\section{Case Study V: The Bhuvanakośa}

The Bhuvanakośa (The Storehouse of Worlds) is a Śaiva text of the tutur genre. This textual source of uncertain dating, probably compiled in different stages, has come down to us through Balinese palm-leaf manuscripts. Comprising about five hundred Sanskrit ślokas accompanied by translations, paraphrases, and/or commentaries in Old Javanese, the Bhuvanakośa is the longest scripture of the tutur class. A common opinion among Balinese and early Western scholars is that the Bhuvanakośa is an early text - probably one of the earliest of the tutur genre. While its formal organization in Sanskrit-Old Javanese translation dyads instead of Old Javanese prose (whether interspersed with Sanskrit ślokas or not) would suggest that this is the case, one can never be sure: witness, for instance, the bulky tutur Sivägama, which is organized in just the same way, and yet was composed by Ida Pedanda Made Sidemen in the first half of the twentieth century. What is important to stress here is that the Bhuvanakośa is a heterogeneous and conglomerative source, formed by at least two textual units that might have been at some point in time (parts of) distinct texts, namely the Brahmarahasya(śästra) (chapters 1-5), and the Jñānasainkșepa/Siddhāntaśästra/Jñānasiddhānta (chapters 6 to 11). The latter chapters are characterized by a remarkable intertextuality with the Jñannasiddhänta discussed in the previous section, which has also been preserved uniquely in Balinese manuscripts, and which shares several Sanskrit verses and similar - yet not identical - paraphrases.

Although the Bhuvanakośa documents a form of Saivism that seems to be related to that of texts of the tattva genre transmitted in Java and or Bali, such as the Dharma Pätañjala, the Vrhaspatitattva, and the Tattvajñana, the text focuses more on yoga and mantric mysticism than metaphysics, and would seem to betray a derivation (or influence) from a different South Asian prototypical tradition. ${ }^{61}$ The Śaiva doctrine shares with the Bhuvanakośa several archaic elements, but some sections of the text present Vedāntic analogies that are found in the Upanișads, as well as in Vedānta-influenced non-dualistic South Indian Saiddhāntika texts. Just in the case of the Jñannasiddhänta, this suggests that the text may be the product of a relatively late Javano-Balinese milieu that appropriated and restated earlier Sanskrit(ic) material, or even composed the Sanskrit verses locally. ${ }^{62}$ Below we quote and analyse two passages that illustrate the different forms of $v y \bar{a} k h y \bar{a}$ textual organization employed by this text.

61 In this respect, one also notes a non-dualistic flavour of many of its theologemes and the use of a Vedāntic terminology, which is a trait of relatively late (post tenth-century) Śaiva texts composed or transmitted in South India. The text may have preserved ancient doctrines that seem to me to be derived by the Sanskrit Upanișadic corpus, in particular the Śvetāśvatara - the earliest theistic/Śaiva Upanișad (whose most recent textual strand might go back to the second or third century CE). But the "philosophical« section of the text, from Chapter 2 to Chapter 4, shares several doctrinal elements in common with the systematic writings of the tattva genre.

62 Indeed, it is entirely possible that the majority of the ślokas of the text were actually composed in Java or Bali, for they are characterized by remarkably non-standard features, metrical oddities, and (very rarely) even contaminations from Old Javanese. Furthermore, virtually none of them has been traced back to Indian texts so far. 


\section{Chapter 7.23:}

sakāro bhagavān viṣnuh / makāro bhagavān śivah /

bhakāro bhagavān brahmā / ekatattvam ${ }^{63}$ trayībhavet $^{64} / / 7.23$

nāhan matanyan viśeșa san̉ hyań śivabhasma / san̉ hyan் trisamaya hana rin bhasma / bhațāra viṣnu sira sakāra / bhațāra śiva sira makāra / bhațāra brahmā sira bhakāra / nā ta lvirnirān tiga dadi eka //

The Lord Viṣnu is the SA, Lord Siva is the MA, Lord Brahmā is the BHA. One reality becomes threefold.

Such is the reason why the holy ashes of Siva are special. The reverend Trisamaya ${ }^{65}$ is in the ashes. The Lord Viṣnu, he is the SA. The Lord Siva, he is the MA. The Lord Brahmā, he is the BHA. Thus is their nature as the three become one.

In this translation dyad, the Old Javanese glosses all the elements of the Sanskrit verse, and at the same time re-contextualizes them into a Balinese framework of speculation revolving around the concept of trisamaya (»the Union of the Three [Gods] «), whereby the three syllables of the word bhasma are connected with the deities of the Trisamaya/Trimūrti, and a ritual praxis called śivabhasma (»The Ashes of Siva"), which is the main topic of the chapter. The Sanskrit $c v i$-verbal compound trayi-bhavet is analysed by the commentator as two separate words, trayi being the subject (as if it were trayah, "triad") and ekatattvaim the object, resulting in an inverted sequence (i.e. three becoming one rather than one reality becoming threefold, as in the Sanskrit). ${ }^{66}$

63 Em.; ekatattva Leiden Cod. Or. 5022, IDGC.

64 Em.; trayibhavet Leiden Cod. Or. 5022, IDGC.

65 OJED, 2040: "(^the meeting of three`?) name of the trinity Brahmā, Wiṣnu, Siwa«.

66 Alternatively, trayi could be a corruption of trayam (however, cf. the similar construction eko eva trayibhavet in Bhuvanakośa 3.74d). 


\section{Chapter 8.25:}

devadaityamanuṣānām / mudrārccaṇavidhikramāt / kunañ ikañ mudrā / mvañ arccaṇa / saha vidhikrama / deva / daitya / ${ }^{67}$ manusya / ya ta phalanya / homabhasman tathā mohà் / kunan் ikañ vvan் mahoma / mabhasma / yan tar vruh rin śaivasiddhān-

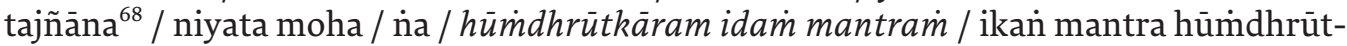
kāra / sakale na tu niṣkalam / rin sakala ikā / kunañ ikan niṣkala / tan mañkana /

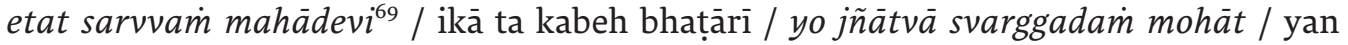
san sādhaka karaktanin mudrārccaṇa / mvan் mantravidhikrama / ya ta tuməmun svarggaphala sira / makahīnanin svargga sira / saka ri pungunnira rin niṣkalajñāna ikā / mama māyāvimohita hị / ikā tañ vvan̉ mañkana / kna denin bañcanañku ikā / mudrārccanavidhin kuryāt / kunan் kagavayanikan் mudrārccaṇa / mvan் vidhikrama ${ }^{71}$

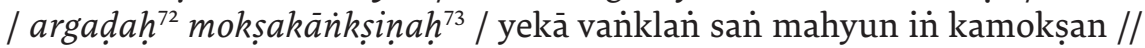

By [following] the right order of the prescribed regimen, worship, and gestures [one will be reincarnated] among gods, demons, and human beings. The fruit of gestures and worship, together with the right order of the prescribed regimen (vidhikrama), is [reincarnation as] gods, demons, and human beings. Similarly, the fire-ritual and ashes [lead] to delusion. The man who performs the fire-ritual and uses ashes, if he does not know the doctrine of the Śaivasiddhānta, is called a »deluded one« indeed. This mantra hümdhrütkäram. The mantra hümdhrütkäram. [Is] in the realm of form, but not the formless. It is within the realm of form. However, the formless is not so.

All this, o Great Goddess. All this, o Goddess. Which bestows heaven, he who knows it because of delusion. If the practitioner is engrossed in gestures and worship, as well as mantras and the right order of the prescribed regimen, he obtains the fruit of heaven. He has heaven as his limit because of his ignorance about the formless gnosis. He is beguiled by my magical power. This kind of man, he is struck by my beguilement. To perform gestures, worship, and the prescribed regimen - The performance of gestures, worship, and the right order of the prescribed regimen - is an impediment for one desiring deliverance. ${ }^{74}$ That would be an impediment for he who desires deliverance. ${ }^{75}$

This passage documents a case of vyākhyā style inserting the Sanskrit directly within the Old Javanese exegesis. The text advances a critique, from a gnostic (Mantramārga) point of view, to the outer-oriented forms of worship associated with Atimārga Śaivism. Hümdhrūtkäram may represent either a local development or a "corruption" of the sound huddun/ huḍduk (huḍdukkära) proffered by the Páśupatas in the course of their ascetic practice. Also remarkable is the usage of the Sanskrit argala (=argada) in the sense of »impediment«. One

67 Em.; vidhikrama / daitya / Leiden Cod. Or. 5022, IDGC.

68 Em.; śivasiddhāntajñāna Leiden Cod. Or. 5022, IDGC.

69 Leiden Cod. Or. 5022; mahädevī IDGC.

70 Em.; māyavimohitaḥ Leiden Cod. Or. 5022, IDGC.

71 Em.; vidhikarmmā Leiden Cod. Or. 5022, IDGC.

72 Em.; arghada Leiden Cod. Or. 5022, IDGC.

MW glosses argala (= argada) as »a wooden bolt or pin for fastening a door or the cover of a vessel; a bar, check, impediment«; compare särgala »obstructed, impeded, prevented «.

75 We accept OJED's (p. 2197) unattested/reconstructed root vainkal* as the basis of amainkal (1) »to get stuck (in the throat, etc.); (2) »unwilling, recalcitrant, savage (elephant).« Thus, the substantive (+ irrealis) vankzla seems compatible with the meaning of the Sanskrit argada. 
could be tempted to take argada not as a separate word but as a compound that would end with mokșakānkșinah (understood as an irregular -a stem in the nominative instead of an -in stem in the genitive), therefore argadamokșakänkșinah might have been intended as meaning "one who desires to be free from an impediment«. But mokșakāinsșin is a cliché in tantric literature, meaning "one desiring release", and the internal doctrinal and logical coherence of the passage requires the interpretation of argada as an »impediment" (i.e., gestures, etc.) holding back the practitioner desiring release. This suggests that the Sanskrit is either a decontextualized quotation from a South Asian text, or the product of a Javano-Balinese milieu.

\section{Conclusion}

In examples from the Amaramālā, SHKM, Vrhaspatitattva, Jñānasiddhānta, and Bhuvanakośa we have observed the use of a vyākhyā model in translation and a "dyadic" mode of composition based on the juxtaposition of Sanskrit verses and their Old Javanese glosses. We have further seen that in the dyadic pattern there is a development from an earlier phase when the glosses align closely with the original to one that allows for an increasingly more flexible approach to the contents of the glosses. In the Vrhaspatitattva this tendency is so pronounced that the Sanskrit verses in many cases do no more than launch an extended doctrinal passage.

Further studies of the dyadic form have shown that it was used as a text-building strategy in the Old Javanese parva literature, but was not limited to it: later texts in the tutur traditions once popular in Sunda, Java, and Bali (and still popular in Bali) show us that the structuring of larger stretches of discourse in terms of "translation dyads " continued to play a major role in text-building, while the Sanskrit-Old Javanese vyākhyā format for glossing at the phrase and clause levels lost none of its usefulness in the field of doctrinal exposition. Metaphysical texts from the tutur tradition like the Ganapatitattva, (parts of) which bear clear signs of late composition, as well as works devoted to ethics and the art of polity (Nìtisära, Ślokāntara, Vratiśäsana, etc.) are among the many texts organized along these familiar lines.

One contribution that this study may have to make is the elaboration of a taxonomy, and perhaps even the opening up of the possibility of a rough chronology for the development of the prose traditions in Old Javanese based on several stages in the use of text-building elements, which we believe ultimately owe their origin to the bilingual pedagogy of religious institutions of Central Java, c. 732-928 CE. While a methodology that pays close attention to formal features of text-building may never be able to provide us with a means for making a completely accurate analysis of the textual chronology of the Javano-Balinese tradition, it may provide us with a metric that can be used alongside other methods of textual analysis to give us a clearer picture of the development of Old Javanese letters. Given that caveat, we will propose here four modes or stages (not necessarily occurring in strictly chronological order) in the development of Old Javanese text-building strategies that appear to align with textual sources from the didactic and prose traditions focused on in this study: 
- A first mode - probably the earliest - where the vyākhya model of translation and a dyadic form of text-building prevails. This stage, represented by the Amaramála , bespeaks a pedagogy that recapitulates the basic style of glossing known from Indian forms of the commentary, but combined with the element of translation that facilitated a "connecting literature«.

- A second mode, illustrated by the SHKM, where vyākhyā translations and a dyadic form of text-building are dominant, but Old Javanese passages elaborating on the śloka include expansions that bring in materials from local perspectives, at the same time demonstrating the ability of the composers to fashion well-formed Sanskrit compounds.

- A third mode where dyadic composition and the vyākhyā format of translation are still prominent, but Old Javanese glosses on Sanskrit verses often develop lengthy doctrinal expositions that move far beyond an exegesis on the meaning of the śloka. While simpler translation dyads are found in the Vrhaspatitattva, many run to extraordinary length.

- A fourth mode, not examined in this chapter, where the śloka-vyākhyā format and "translation dyads" have been adopted for the needs of prose works like the parva literature and Tantri Kāmandaka.

From this study we can conclude that the apparent lack in the archipelago of commentarial tradition parallel to that of South Asia reveals to us not the absence of a tradition of commentary, but exactly the opposite: the norms of the South Asian commentary were so deeply embedded in the pedagogy of religious institutions that they left indelible traces on all that was to follow.

We would like to conclude this essay with some theoretical reflections on the nature of the texts discussed here in the cadre of Western ideas of translation, paraphrase, and commentary, as well as the methodology of philological research. Recent philological work on Sanskrit and vernacular languages of South and Southeast Asia has shown an increasing interest in the reception of texts. Indic texts were historically malleable and were reinterpreted by their audiences in different geographical contexts and epochs, all the more so in Java and Bali, where the textual tradition was considerably open to creative reuse rather than faithful reproduction of a canonical prototype. In the case of the Old Javanese textual tradition and its continuation in Bali, one may say that local authors and copyists were not moved by the intent to faithfully translate the Sanskrit sources and interpret them in a manner that is coherent with those elaborated within the prototypical religio-philosophical traditions they stem from; rather, Sanskrit materials - often fragmentary, and perhaps composed centuries before - in the Indian subcontinent were de-contextualized and interpreted in the light of local beliefs and practices. That is to say, an Indic textual tradition transmitted to Southeast Asia was transformed and adapted into contextually appropriate and meaningful styles and genres.

Thus, Old Javanese texts can be regarded as reflecting a conversation between "Indic" and »vernacular« elements. Old Javanese literature was far from being a derivative, translation-oriented endeavour, but from its very inception showed the traits of originality and synthesis, implying a conscious selection of essential elements that resonated within the local culture and the creation of a new whole that met the demands of the local audiences. These "wholes " inevitably varied across time, local contexts characterized by different histories of reception, socio-cultural factors, and religious contingencies, as well as individual agents, although one notes a remarkable resilience of the pedagogical and formal features 
characterizing the genres discussed in this article. Texts composed (or recompiled) in Bali after the fifteenth century carried meanings that were quite different from those they had in their original milieu, possibly in pre-tenth-century Central Java, and Sanskrit materials were understood, appropriated, and restated in Old Javanese in ways that would often be at odds with both a Western philological and a South Asian »traditional«/śāstric understanding. Inevitably, this local »restating " of Sanskritic religious texts and traditions involves a certain amount of "falsification " to create new meanings in context. While this is a totally legitimate process, philology should not shy away from identifying and explaining any textual errors, contaminations or variants alongside the local interpretations and restatements, which will, all together, contribute to our better understanding of Balinese linguistic, orthographic, lexical, grammatical, narrative, and conceptual understandings (and misunderstandings) and practices in their historical dimension. ${ }^{76}$

\section{Acknowledgements}

Andrea Acri would like to acknowledge that research represented in parts of this work was conducted within the programme »Scripta-PSL. Histoire et pratiques de l'écrit« (principal investigators: Andrea Acri, EPHE, PSL and Arlo Griffiths, EFEO, PSL), »Investissements d'Avenir « launched by the French Government and implemented by ANR (ANR-10-IDEX-0001-02 PSL).

76 While making a case in favour of a philology that is more concerned with reception and variance than establishing »original« texts, Pollock (Philology, 406) still advocates for »a scale of judgment in reading tradition «, according to which "not all interpretations are worthy of philological attention to the same degree. People in a tradition inherit bad textual variants, or make simple grammatical mistakes, and these misunderstandings, unless they are productive of interpretation, carry a dimension of historical consciousness lower on the philological scale of value than others. In other words, not all errors [...] are equal: some falsehoods (or what appear to be falsehoods) carry deeper truths than others, especially in their historical effectivity«. 


\title{
References
}

\author{
Abbreviations \\ MW = Monier Williams' Sanskrit-English Dictionary (Monier-Williams, 1899) \\ OJED = Old Javanese-English Dictionary (Zoetmulder and Robson, 1982) \\ SHKM = San் Hyàn Kamahāyānan Mantranaya \\ WMP = Western Malayo-Polynesian
}

\section{Manuscript sources}

Amaramālä (within the Candrakiraṇa), palm-leaf ms. (gebang) L631, Perpustakaan Nasional Republik Indonesia.

Bhuvanakośa, (1) palm-leaf ms. (lontar) Cod. Or. 5022, Leiden University Library; (2) palmleaf ms. (lontar) IDGC, private collection of Ida Dewa Gede Catra, Amlapura, Karangasem, Bali.

Saǹ Hyà் Kamahāyānan Mantranaya, palm-leaf ms. (lontar) Cod. Or. 5068, Leiden University Library.

Aichele, Walter, Vergessene Metaphoren als Kriterien der Datierung des altjavanishen Rāmāyaṇa, Oriens Extremus: Zeitschrift für Sprach, Kunst und Kultur der Länder des Fernen Ostens 16 (1969) 127-166.

Acri, Andrea, Dharma Pātañjala: A Śaiva Scripture from Ancient Java Studied in the Light of Related Old Javanese and Sanskrit Texts (second edition) (New Delhi, 2017).

Acri, Andrea (ed.), Esoteric Buddhism in Mediaeval Maritime Asia: Networks of Masters, Texts, Icons (Singapore, 2016).

Acri, Andrea, On birds, ascetics, and kings in Central Java: Rāmāyaṇa Kakawin, 24.96-126 and 25, Bijdragen tot de Taal-, Land-en Volkenkunde 166 (2010) 475-506.

Acri, Andrea, Re-configuration of divinity in Old Javanese Śaiva texts from the Indonesian Archipelago (with special reference to Jñänasiddhānta, chapter 19), in: s.n., Travaux de Symposium International: Le Livre. La Roumanie. L'Europe. Troisième édition, Tome III (Bucharest, 2011) 546-565.

Acri, Andrea, The Sanskrit-Old Javanese tutur literature from Bali: The textual basis of Śaivism in ancient Indonesia, Rivista di Studi Sudasiatici 1 (2006) 107-137.

Acri, Andrea, The Vaimala sect of the Pāśupatas: New data from Old Javanese sources, Tantric Studies 1 (2008) 193-208.

Braginsky, Vladimir, The System of Classical Malay Literature (Leiden, 1993).

Brunner, Hélène, Analyse du Kiraṇāgama, Journal Asiatique 253 (1965) 309-328.

Brunner, Hélène, Analyse du Suprabhedāgama, Journal Asiatique 255 (1967) 31-60.

Davis, Richard H., Ritual in an Oscillating Universe: Worshiping Siva in Medieval India, (Princeton, 1991).

Goodall, Dominic, Bhațta Rāmakanțha's Commentary on the Kiraṇatantra, Vol. 1: Chapters 1-6 (Pondicherry, 1998).

Goodall, Dominic (ed.) Hindu Scriptures (Los Angeles, 1996).

Goris, Rulof, Bijdragen tot de Kennis der Oud-Javaansche en Balineesche Theologie (Leiden, 1926). 
Dīpankarabhadra, Guhyasamājamandalavidhi, ed. Sabine Klein-Schwind, rev. H. Isaacson (based on ms. Niedersächsische Staats- und Universitätsbibliothek Göttingen, Cod. ms. sanscr. 257), (2008). e-text downloaded from https://www.tantric-studies.uni-hamburg. de/research/e-texts/buddhist-e-texts/gusamavi.txt (accessed May 2020)

Hevajrasekaprakriyā, ed. Louis Finot, Manuscripts sanskrits de sädhana's retrouvés en Chine, Journal Asiatique 225 (1934) 1-85.

Hooykaas, Christiaan, Śaiva Siddhānta in Java and Bali: Some remarks on its recent study, Bijdragen tot de Taal-, Land-en Volkenkunde 118 (1962) 309-327.

Hunter, Thomas M., Bahasa Sanskerta di Nusantara: terjemahan, pemribumian, dan identitas antardaerah, in: Henri Chambert-Loir (ed.), Sejarah Terjemahan di Indonesia dan Malaysia (Jakarta, 2009) 23-47.

Hunter, Thomas M., The Bhagavad-Gìtā sections of the Old Javanese Bhișmaparwa, text-building and the formation of the state in pre-modern Indonesia, in: Shyam Saran (ed.), Cultural and Civilisational Links between India and Southeast Asia: Historical and Contemporary Dimensions (Singapore, 2018) 193-207.

Hunter, Thomas M., The Impact of Indian Forms of the Commentary on Text-building Strategies in Old Javanese. Unpublished seminar paper (Pondicherry, 2005).

Hunter, Thomas M., Translation in a world of diglossia, in: Jan van der Putten and Ronit Ricci (eds.), Translation in Asia: Theories, Practices, Histories (Manchester, 2011) 9-26.

Hunter, Thomas M., Yati, a structural principle in Old Javanese versification, Indo-Iranian Journal 52 (2009) 1-52.

Ishii, Kazuko, The correlation of verses of the Sang Hyang Kamahàyannan Mantranaya with Vajrabodhi's Jāpasūtra, Area and Culture Studies 44 (1992) 225-236.

Jordaan, Roy E. and Brian E. Colless, The Mahäräjas of the Isles, the Śailendra and the problem of Śriwijaya (Leiden, 2009).

de Jong, Jan Willem, Notes on the sources and the text of the Sang Hyang Kamahäyanan Mantranaya, Bijdragen tot de Taal-, Land- en Volkenkunde 136 (1974) 619-636.

Kandahjaya, Hudaya, Sàn Hyan Kamahāyānikan, Borobudur and the origins of Esoteric Buddhism in Indonesia, in: Andrea Acri (ed.), Esoteric Buddhism in Mediaeval Maritime Asia (Singapore, 2014) 67-112.

Kats, J., Sang Hyang Kamahāyānikan: Oud-Javaansche tekst met inleiding, vertaling en aanteekeningen (The Hague, 1910).

Kriyāsañgrahapañikika, ed. Ryugen Tanemura, E-text based on a preliminary edition of the Kriyāsamgrahapañjikā, Chapter 6. Unpublished $\mathrm{PhD}$ thesis (University of Oxford).

Krom, Nicolaas J., Hindoe-Javaansche Geschiedenis (The Hague, 1926).

Lokesh Chandra, Chanda-Karana: The art of writing poetry, in: Lokesh Chandra, Cultural Horizons of India, Vol. 6: Studies in Tantra and Buddhism, Art and Archaeology, Language and Literature (New Delhi, 1997).

Lokesh Chandra, Sanskrit studies in classical Indonesia, in: Lokesh Chandra (ed.), Cultural Horizons of India, Volume 4: Studies in Tantra and Buddhism, Art and Archaeology, Language and Literature (New Delhi, 1995) 1-9.

Miksic, John, Borobudur: Golden Tales of the Buddhas (London, 1990).

Monier-Williams, Monier, Sanskrit-English Dictionary (Oxford, 1899).

Nihom, Max, Studies in Indo-Indonesian Tantrism: The Kuñjarakarnadharmakathana and the Yogatantra (Vienna, 1994).

Oglobin, Alexander K., Irrealis in Old Javanese. Unpublished seminar paper (Depok, 2005). 
Pollock, Sheldon, The Language of the Gods in the World of Men: Sanskrit, Culture, and Power in Premodern India (Berkeley, 2006).

Pollock, Sheldon, Philology in three dimensions, Postmedieval: A Journal of Medieval Cultural Studies 5/4 (2014) 398-413.

Pollock, Sheldon, The Sanskrit cosmopolis, 300-1300 CE: Transculturation, vernacularization, and the question of ideology, in: Jan E. M. Houben (ed.), Ideology and Status of Sanskrit: Contributions to the History of the Sanskrit Language (Leiden, 1996) 197-248.

Radicchi, Anna, More on the Kãrakasaṃgraha, a Sanskrit grammatical text from Bali, in: Jan E. M. Houben (ed.), Ideology and Status of Sanskrit: Contributions to the History of the Sanskrit Language (Leiden, 1996) 289-306.

Raj Pant, Mahesh, Jațarüpa's Commentary on the Amarakośa, Parts 1 and 2 (New Delhi, 2000).

Sarkar, Himamsu Bhushan, Corpus of the Inscriptions of Java (Corpus Inscriptionum Javanicarum), up to 928 A.D. (Calcutta, 1971).

Sarvabuddhasamāyoga: Śrīsarvabuddhasamāyogadākinījālasamvaranāmatantram (1-8), ed. Ṭhākurasena Negī, Dhīh: Journal of Rare Buddhist Texts Research Project 58 (2018) 141201.

Sudarshana Devi, Wrhaspati-tattwa, an Old Javanese Philosophical Text (New Delhi, 1957).

Soebadio, Haryati, Jñānasiddhānta: Secret Lore of the Balinese Śaiva Priest (The Hague, 1971).

Speyer, Jacob S., Ein altjavanischer mahāyānistischer Katechismus, Zeitschrift der Deutschen Morgenländischen Gesellschaft 67 (1913) 347-362.

Wulff, Kurt S., Sang Hyang Kamahāyānan Mantrānaya: Ansprache bei der Weihe buddhistischer Mönche aus dem altjavanischen übersetzt und sprachlich erläutert (Copenhagen, 1935).

Zieseniss, Alexander, Studien zur Geschichte des Śivaismus: Die Śaiva-Systematik des Vrhaspatitattva (New Delhi, 1958).

Zoetmulder, Petrus J., Kalangwan: A Survey of Old Javanese Literature (The Hague, 1974).

Zoetmulder, Petrus J. and Stuart O. Robson, Old Javanese-English Dictionary (The Hague, 1982). 